\title{
Raiding as a Treat to Economic Security of Kuzbass Coal Mining Enterprises
}

\author{
Tatyana Tuleneva ${ }^{1, *}$ \\ ${ }^{1}$ T.F. Gorbachev Kuzbass State Technical University, 650000 Vesennya st. 28, Kemerovo, Russian \\ Federation
}

\begin{abstract}
The paper deals with the phenomenon of raiding, which has become widespread and poses a threat to economic security of Russia in recent years. The wave of raiding is aimed at coal mining enterprises of Kuzbass, which have a stable holding structure and rising property prices due to development of strategic markets. In Russia almost all cases of hostile acquisition are accompanied by violation of civil, administrative, financial and criminal legislation. Raiding the market for corporate control caused by imbalance of current structure of ownership and control. The effect of raider acquisitions is damage to economy, social sphere and investment climate of Kuzbass and Russia. More aggressive and less civilized nature of raider acquisitions in Russia in comparison with other countries is conditioned by the specifics of socio-economic and institutional environment. In this regard, raiding in Russia doesn't lead to effective distribution of rights to economic assets, but to aggravation of socio-economic and legal problems. Development trends of raiding currently characterized by a growing number of participants and complexity of forms of hostile acquisitions and ways of providing exposures.
\end{abstract}

\section{Introduction}

In the context of reforming modern Russian society, issues related to strengthening of the system of national and economic security focused on ensuring stable development of society and state, their protection from economic threats, are of particular importance. One of threats to economic security is the phenomenon of raiding, which has become widespread in Russian Federation in recent years. Numerous raider acquisition are shaking country's economy and as a result is criminal redistribution of property. In fact, raiding has become one of types of high-income business, profitability of which reaches $1000 \%$. At the same time, only $10 \%$ of total number of acquisition entail initiation of criminal proceedings. Even smaller percentage from it finish in litigation [1].

As a criminological phenomenon, raiding is international in nature and is the subject of a joint struggle of law enforcement agencies of many states in changing economic relations. Raiders`actions are not limited to the acquisition of national business, but tend to encroach on transnational companies and holdings, with using of financial and banking systems.

\footnotetext{
${ }^{*}$ Corresponding author: kta.bua@kuzstu.ru
} 
The wave of raiding began to move to regions, because in Russia's center property is already divided and securely protected. Coal-mining enterprises of Kuzbass aren't left without raiders' attention. Following publications about the attempts of their raider acquisitions have been in the media in recent years [2].

1. In 2013 trade Union activists of LLC «Coal company «Zarechnaya», mines «Oktyabrskaya» and «Aleksievskaya» sent a letter to the Prosecutor General of Russian Federation Yuri Chaika, the Chairman of ICR Aleksander Bastrykin and the Chairman of SAC RF Anton Ivanov about an attempt to raider seizure of enterprises belonging to group LLC «Coal company «Zarechnaya». The letter referred to demand of the former Prosecutor General and representative of the Presidential Administration of Ukraine to transfer $50 \%$ of assets according to «oral agreements» many years ago. Pressure is exerted by filing lawsuits, including in foreign courts. These actions led to destabilization of enterprises, caused debts to budgets of different levels, as well as failure of part of social programs.

2. In 2017 there was an attempt to raider's acquisition of mine «Anzherskaya-Yuzhnaya» with using of force measures. Armed men in masks announced change of leadership, didn't allow on a territory of the mine more than 300 miners, expelled employees from offices of the enterprise, and also tried to turn coalface off power supply, where there were miners. Employees of Main investigation department of the Main investigation department of GD IAM of Russia in Kemerovo region managed to come to organizer's trail of action, "which immediately went by plane to Moscow after committing illegal actions, where he was detained by local police in an airport « (as it was said in a press release GD IAM). Prerequisites of these actions was the bankruptcy procedure of LLC «JED Block № 2 of mine «Anzherskaya-Yuzhnaya», and one of the first decisions of the new bankruptcy trustee was a ban on shipment of coal in the continuation of its production (that means the actual stopping of coal mining after filling the coal warehouse), and also his decision to transfer functions of security to another company, which was represented by people in masks.

Expansion of central capital takes place on the periphery, including through raider seizure of property. Main waves of raiding have already passed. Wave of raiding is moving to Kuzbass from Moscow, and this is explained by the fact that all key events that give impetus to this wave are taking place just in the capital [3]. The reason for waves is the interest in certain markets. Industry at some period becomes extremely attractive, as a rule raiding is transferred to places having a stable structure, in particular, in coal mining industry tendency to creation of holding structures was formed. Another trend is an attractiveness for raiders of large cities, where price of property and land increases as strategic markets develop [4].

\section{Materials and methods}

Today raiding on the corporate control market is recognized as one of the most acute and contradictory problems of domestic business. At the same time, problem remains insufficiently studied to date. Well-known issues devoted to analysis of separate aspects of raiding: main technology corporate acquisitions, prevention and intervention methods to counter hostile acquisitions, protection of immovable property of enterprises, etc. However, as the phenomenon in general, raiding remains incompletely investigated. There are still no answers to many other important questions for theory and economic practice, for example: what are essential features of raiding can separate it from other activities in corporate control market, what factors influence spread of raiding, what impact it has on economy as a whole, what should be state policy in relation to this problem [5]. Lack of a common understanding of essence of raiding and trends in its development blocks possibility of 
developing an effective state policy to counter raider attacks, so studying of raiding is an urgent scientific and applied task.

Economic consequences of raiding are determined by destruction of production facilities, deterioration of investment climate, losing of leading positions in innovative technologies. Raiding disturbs to develop medium-sized businesses in Russia. It blocks development of civilized competition, destroys property relations as foundations of market economy and threatens to slow economic growth. Due to large-scale raiding operations, coal mining industry of Kuzbass has been almost closed to non-administrative resources of both Russian and foreign investments.

Raiding in corporate control market occurs due to systemic mismatch between existing ownership structure and control and the stage of economic development. In such circumstances, activity of raiders leads to activation of processes in the market of corporate control and promotes transfer of assets between owners. Will raiding lead to achievement of an equilibrium distribution of rights in the economy depends on characteristics of socioeconomic and institutional environment, because they determine dominant types and forms of raider actions [6]. Raiding is formed in those types and forms which allow to resolve system contradictions in structure of property and control only under condition of effective protection of rights in economy. In Russia corporate raiding has accelerated development of the market of corporate control and ensured distribution of assets between agents of economy. However specifics of socio-economic and institutional environment determined more aggressive and less civilized nature of raider actions in Russia in comparison with other countries. In this regard, raiding in Russia leads not only to achievement of effective distribution of rights to economic assets, but also to aggravation of socio-economic and legal problems [7].

Issues of Russian raiding practice point to ongoing transformation of this business throughout the period of its existence. Now raiding has passed the stage of origin, entering the stage of looking for new directions and forms. The number of participants in raider acquisitions is expanding, forms of raider actions are becoming more complex, ways of influencing opponents are changing, composition of acquired companies is being transformed. The profitability of raiding in its current form and forms is reduced, and risks of projects are increasing [8]. This fact can lead either to a significant reduction in the number of raider acquisitions, or to a new transformation of raiding. Absence of effective state policy to counter raiding can lead to more aggressive types and forms of property redistribution.

Mass seizures of property became in Russia common but they cause range of problems. For example, growing distrust of businessmen who are unable to even defend himself, and to the state that cannot guarantee property rights [9]. Businessmen don't realize the need to develop their business, which at any time can be taken off, if the government doesn't guarantee safety of invested funds.

Raiders' actions directly disturb implementation of state economic programs that involve acquired enterprises. Rigid and conflict methods of solving problems, typical for raiding, leave their mark on corporate culture of business groups prone to it, and it creates an unfavorable image. The other side of raider business culture is an increased risk of difficulties in relations with partners. Specific raider culture is able to destroy not only traditional fields of business, but also political life of the region.

Ongoing state policy of counteraction to raiders ignores the possibility of using economic instruments affecting the practice of acquisitions, and doesn't take into account the fact that raider structures are heterogeneous and affect all in one way hardly makes sense. Although Russian legislation provides for protection against raiding, in reality law enforcement practice on this issue is quite poorly developed. 
More specific ways of protection against raiding include strengthening the security system of coal mining enterprise, including hiring of armed guards for both apartments of an enterprise and for its leaders; ensuring the security of business documents, primarily the constituent, financial and personnel; obtaining a small loan from a banking institution secured by enterprise's property, in this case, there will be another way to force raiders to eliminate their plans (but this scheme works only if bank is reliable); distribution of existing contracts to affiliated organizations; repayment of all taxes and lease payments, which will exclude possibility of using debts to acquisition the business [10].

A regional coal mining enterprise is an object of raider activity depending on investment appeal of Kuzbass owing to low cost of assets (in comparison with the enterprises in European part of Russia), interest of administration of Kemerovo region in external financing (because of insufficient financing from own budget and budgets of the highest levels). Thus, coal mining enterprises of Kuzbass are quite vulnerable to investorsacquirers. From the raider's point of view many factors affect on the choice of the target company. There are several features of the target company that make it attractive for hostile acquisition: compliance of target company's activity goals with strategic goals of the customer company; the target company is promising and highly profitable; availability of attractive assets (primarily immovable property with land); conflicts among shareholders.

Raiding as a type of criminal activity having an organized character is carried out with using of gaps in current legislation/ It is based on corruption, using of state, administrative and power resources and represents a real threat to the economic security of Russia. Due to the fact that legislative, executive and law enforcement agencies don't have a common understanding of key concepts for competent and purposeful struggle against raiding, implementation of legislative initiatives is significantly decelerated. Current criminal legislation of Russia also doesn't meet real criminal situation in the sphere of raiders' acquisitions, and this fact prevents development of common approaches to fight against them.

An important reason for raider acquisition is low level of business culture. Owners of coal mines rarely think about the fact that their business may be acquired by raiders [11]. They think about business development, relations with administrative authorities, but rarely think about potential acquisition. Lack of business culture is also occurred in violation tax, labor, civil legislation by businessmen. The problem also lies in insufficient development of risk management or in inefficiency of its using. Today large companies realize that it is profitable to keep qualified lawyers in their staff, but small businesses are still not protected because of their financial insolvency.

Raiding is one of additional risks for investment, although it is compensated by high profits due to favorable economic conditions. Business community is now actively withdrawing capital reserves abroad to be able to do business in conditions of a deterioration situation. The highest outflow of capital abroad today is a result of raiders' acquisitions. Raiding not only defames economic policy of the state, but also destroys Russia's prestige in the international arena. For us it is customary that someone was taken away from the plant, but in any civilized country it is shocking. These events are routine for us, they think the ones shaking moral foundations. Image damage is so great that it prevents with innovation policy. Russia continues to be perceived as a country of «great lawlessness». Some of challenges facing the country in conditions of widespread raiding are simply unrealistic. In particular, transition to an innovative economy is absolutely unrealistic. Businessmen are afraid of starting business and working legally [12]. As soon as the businessman starts business, the chance of acquisition dramatically increases.

Raiding leads to certain consequences in social terms, such as increasing level of corruption in the state, loosing employing places and salaries, etc. So raiding is dangerous as a social factor. Raiding is a type of shadow economy, and it is not a cause, but a 
consequence of the current system of economic, social and political relations. Raiding very often acts in interests of large government officials who simply earn their informal money.

\section{Results and discussion}

It is possible to consider following vulnerability factors of the coal mining enterprise for raider acquisitions [13].

1. Poorly structured shareholders' property, that means absence of owners of large blocks of shares (shares). Russian owners have already passed this stage, and now they are trying to build a structure of the share property to accumulate shares packages (shares) from several owners as much as possible, and also to avoid minority shareholders in the structure of the share property. Using corporate racketeering, they can block joint-stock company's management by filing multiple lawsuits to courts. Thus, minority shareholders make it clear that litigate them will be more expensive than buying shares at a price much higher than the market.

2. Creation vertically or horizontally integrated holding companies in coal mining industry. Objective reality of today's global economy is business enlargement. Concentration of financial and industrial capital makes it possible to respond to market demands and establish its terms. The goal of integration is always to increase production efficiency and profitability. Such integration is often a motive for hostile acquisition, but usually through legitimate means.

3. Underestimation of securities (business), including due to underdevelopment of the securities market. Often assets of the coal mining enterprise are underestimated, and therefore raiders try to buy business cheaper and sell it more expensive.

4. Low legal culture of shareholders and other owners of assets. Most of enterprises subjected to raider acquisition, become irresponsible and passive. Its constituent documents and contracts are template, and nobody thought about creation internal documents regulating corporate procedures. Earlier previously registration authorities were assigned functions of control compliance procedure of creating a business with requirements of legislation, but now these functions have been removed from them. Therefore, all responsibility for the preparation of documents and their availability are business owners.

5. Frequent checks by control services. At the same time it is required to submit a large volume of documents on economic activity. The more raiders have any information about the target company, the easier it is to work for them. Any raider acquisition begins with gathering information. Management often doesn't know its rights when communicating with regulatory authorities and fulfils all its requirements, even if inspectors exceed their authority.

6. High concentration of accounts payable by several partners, dependence of the coal mining enterprise on several suppliers or sellers.

7. Presence of corporate conflicts weakens the coal mining enterprise and makes it more vulnerable. Despite the potential threat, the majority of enterprises doesn't pay due attention to preventive protection and seek the help of specialists only when the threat of business loss becomes apparent. However using of preventive measures of protection allows to counter acquisition as effectively as possible. A complex of protective measures developed individually for each enterprise taking into account its specifics and peculiarities, needs to cover all aspects: legal, financial, social, etc., that would eliminate or substantially reduce the possibility of acquisition.

Will the wave of raiding stop or will not, it depends on the position of the state, whether it will make this problem a priority [14]. The fight against raiding requires political will. It needs more consolidated business that can defend its real interests. On the one hand, the state gradually realizes danger of raiding, on the other hand, businessmen become more 
experienced and more qualified. Finally, the profitability of raiding as a business is falling every year [15]. If its profitability falls to a normal level, then raiding will move to more legal forms of asset building and to civilized mergers and acquisitions. In addition, if an international legal framework on competition policy will appear, disputes about hostile acquisition will be resolved on a civilized basis.

\section{Conclusion}

Creation of Russian institute of raiding is connected with imperfection of market instruments of redistribution of property, absence regular market assessment of liquid assets of enterprises, unclear system of property rights registration, low information clarity of data of coal mining enterprises, growth of corporate conflicts connected with imperfection of corporate legislation. All these facts contribute to development of mechanisms of acquisition of property in the non-market sector of corporate control and changing the form of «economic terrorism» through raiding, aimed at replacing the owner of both the enterprise and part of its property. Waves of raider acquisitions from the center are moving to regions with a certain delay and diversified technology acquisition coal mining enterprises, acquiring features of the macroeconomic phenomenon.

Raiding is objectively related to such threats to economic security as increased unemployment, tax evasion, monopolization of a number of market segments, destruction and decline of production, loss of competitiveness, discredit the Federal and regional authorities, deterioration investment climate, activation of processes of obtaining money illegally.

\section{References}

1. N. Anderson, The Journal of Labor and Society. 9:2, 225 (2006)

2. C. Alger, NYU Journal of Law and Business, 3, 309 (2006)

3. E. Demidova, Problems of Economic Transition, 50:5, 44 (2007)

4. T. Firestone, The International Lawyer, 42:4, 1207 (2008)

5. A. Kireev, Problems of Economic Transition, 50:8, 29 (2007)

6. J. Armour, D. A. Skeel, Georgetown Law Journal, 95, 1727 (2007)

7. A. Ledeneva, Comparative Studies in Society and History, 50:1, 118 (2008)

8. I. Kasparova, Problems of Economic Transition, 50:5, 61 (2007)

9. J. Pearce, R. Robinson, Business Horizons, 47:5, 15 (2004)

10. B. Black, R. Kraakman, A. Tarassova, Stanford Law Review, 52, 1731 (2000)

11. E. Burger, The International Lawyer, 38:1, 15 (2004)

12. K. Darden, Politics and Society, 36:10, 35 (2008)

13. I. Iwasaki, Problems of Economic Transition, 50:5, 73 (2007)

14. A. Osipian, Innovation: The European Journal of Social Science Research, 23:2, 101 (2010)

15. T. Dolgopyatova, Problems of Economic Transition, 50:5, 7 (2007) 